Pediat. Res. 2: 514--518 (1968)

Developmental microsomes

pharmacology pharmacometabolism

liver pituitary gland

tumor

\title{
Prevention of the Normal Postnatal Increase in Drug-Metabolizing Enzyme Activity in Rat Liver by a Pituitary Tumor
}

\author{
JOHN T.WILSON ${ }^{[21]}$ \\ Section on Endocrinology, Reproduction Research Branch, National Institute of Child Health \\ and Human Development, National Institutes of Health, Bethesda, Maryland, USA
}

\begin{abstract}
Extract
A transplantable pituitary mammotropic tumor ( $\mathrm{MtT}$ ) was grown in male rats of various ages to serve as a source of somatotropin (growth hormone), corticotropin (adrenocorticotropic hormone, ACTH) and prolactin. The development of the microsomal enzyme system that oxidizes hexobarbital, demethylates aminopyrine to form formaldehyde, and produces p-aminobenzoic acid by the reduction of p-nitrobenzoic acid was studied in liver from control and tumor-bearing rats.

In control rats, adult levels of drug metabolism were found at 46 days of age for p-nitrobenzoic acid and at about 60 days of age for hexobarbital and aminopyrine (fig. 1). In MtT-bearing rats, however, the normal postnatal increase in the liver enzyme system which metabolizes hexobarbital, aminopyrine, and p-nitrobenzoic acid did not occur.

Since phenobarbital pretreatment of young control rats produced an increase in hepatic microsomal drug-metabolizing enzyme activity, young rats with the MtT were injected with phenobarbital. Growth of the $\mathrm{MtT}$ in young rats did not prevent an increase in the liver metabolism of hexobarbital or the production of formaldehyde from aminopyrine normally found to follow phenobarbital treatment (table II). Thus, while endogenous pituitary tumor somatotropin, corticotropin and prolactin may have prevented the normal maturation of the liver drug-metabolism enzyme system, enhancement of this enzyme system occurred after phenobarbital pretreatment of $\mathrm{MtT}$-bearing young rats.
\end{abstract}

\section{Speculation}

The decreased activity of microsomal drug-metabolizing enzymes in liver from young rats with high levels of somatotropin, corticotropin and prolactin in blood, compared with that from control animals, suggests that these pituitary hormones, singularly or in combination, may affect the activity as well as the postnatal development of this enzyme system in the rat. A relation between blood levels of these hormones and liver drug-metabolizing enzyme activity in young animals of various species may exist. A possible interrelation between liver drug-metabolizing enzyme activity and high blood levels of somatotropin in newborn infants may also exist.

\section{Introduction}

Young animals of many species have a level of activity of the hepatic microsomal drug-metabolizing enzyme (HMDM) which is lower than that found in adults. In liver from rats [14], guinea pigs and mice [13], or rabbits $[7,9]$, the metabolism of some drugs increases to adult levels within the first week of life. Fours [6] suggested that this enzyme activity was low in newborn and fetal rabbit liver because the synthesis of enzyme 
protein for HMDM was lower in the young animal. He found that the administration of phenobarbital to young rabbits increased the hepatic microsomal metabolism of several compounds. The observation, however, that HMDM activity normally increased after birth suggested that endogenous factors regulated the level of activity of this enzyme. Such regulation may be mediated by several anterior pituitary hormones, but an interaction between changes in blood levels of anterior pituitary hormones and the increase in HMDM in young animals has not been reported.

BATEs et al. [1] found high levels of somatotropin, corticotropin and prolactin in blood of rats bearing a pituitary mammotropic tumor ( $\mathrm{Mt} \mathrm{T})$. In the present study, this tumor was implanted in male rats of various ages in order to observe the effect of this tumor on the development of the liver enzyme system which metabolizes hexobarbital, aminopyrine and p-nitrobenzoic acid.

\section{Methods}

\section{Preparation of Tumor}

The transplantable MtT [10] was excised from donor Fischer rats and homogenized with three parts of $0.9 \%$ aqueous saline. The homogenate was injected subcutaneously ( $2 \mathrm{ml} / 100 \mathrm{~g}$ body weight) into male Fischer rats of various ages (table $\mathrm{I}$ ). Animals were placed in suspended wire cages and given Purina rat pellets and water ad libitum. The lights of the animal room were turned on (day) and off (night) at 12-hour intervals. Young rats were weaned at 21 days of age. Tumor-bearing rats did not appear cachetic or sick. Rats were exanguinated under ether anesthesia, and organomegaly, adrenal enlargement, and in increase in the amount of mammary tissue and/or milk production in $\mathrm{MtT}$-bearing rats were used as an indication of high levels of somatotropin, corticotropin and prolactin in blood respectively [19].

\section{Biochemical Reactions}

Livers were excised and homogenized ( $1 \mathrm{~g}$ liver plus $2 \mathrm{ml}$ of $1.15 \% \mathrm{KCl}$ ) in a glass homogenizer with a teflon pestle. The liver homogenate was centrifuged at $9000 \times \mathrm{g}$ for 20 minutes, and the supernatant fraction $(0.25 \mathrm{ml})$ was added to a reaction mixture which contained cofactors and substrate. One milligram of adult liver microsomal protein $/ \mathrm{ml}$ of the reaction mixture (equivalent to $0.25 \mathrm{ml}$ of liver $9000 \times \mathrm{g}$ supernatant fraction $/ 2.5 \mathrm{ml}$ reaction mixture) was found by Schenkman et al. [16] and by us to be optimal for the formation of formaldehyde from aminopyrine under the reaction conditions described. The concentration of cofactors and substrates in micromoles $/ 2.5 \mathrm{ml} \mathrm{mix-}$
Table I. Implantation age and duration of tumor growth in young male rats ${ }^{1}$

\begin{tabular}{lccc}
\hline $\begin{array}{l}\text { Age of rat } \begin{array}{l}\text { Nhen tumor } \\
\text { implanted } \\
\text { (days) }\end{array} \\
\text { when studied }\end{array}$ & $\begin{array}{c}\text { Age of rat } \\
\text { when }\end{array}$ & \multicolumn{2}{c}{$\begin{array}{c}\text { Number of rats } \\
\text { per group }\end{array}$} \\
\cline { 3 - 4 } & (days) & Control & MtT \\
\hline- & 5 & $3^{2}$ & - \\
- & 17 & 7 & - \\
- & 31 & 7 & - \\
3 & 46 & 8 & 8 \\
16 & 58 & 8 & 8 \\
31 & 73 & 6 & 2 \\
46 & 87 & 6 & 5 \\
61 & 101 & 5 & 4 \\
92 & 131 & 5 & 4 \\
136 & 172 & 5 & 5 \\
195 & 230 & 6 & 5 \\
\hline
\end{tabular}

1 Two milliliters of $\mathrm{MtT}$ homogenate (equivalent to $0.5 \mathrm{~g}$ of tumor) per $100 \mathrm{~g}$ body weight were injected subcutaneously into young male Fischer rats. The tumor was allowed to grow for 35-43 days.

2 Three samples of pooled rat liver (4 livers/sample) were used.

ture were: glucose-6-phosphate, $12.5 ; \mathrm{MgSO}_{4}, 12.5$; nicotinamide adeninedinucleotide phosphate (NADP), 2.08; hexobarbital, 1.5; aminopyrine, 20 [11]; and p-nitrobenzoic acid, 15. Nicotinamide was omitted from the incubation mixture [16]. The volume of the reaction mixture was adjusted to $2.5 \mathrm{ml}$ with $0.1 \mathrm{M}$ potassium phosphate buffer, $\mathrm{pH} 7.35$; when formaldehyde was measured, semicarbazide $\mathrm{HCl}(25 \mu$ moles/ $2.5 \mathrm{ml}$ ) was added to the mixture as a trapping agent. The hepatic side chain oxidation of hexobarbital (measured by substrate disappearance [4]) and the formation of formaldehyde by demethylation of aminopyrine $[3,15]$ were determined after incubating the reaction mixture for 30 minutes at $37^{\circ}$ under an atmosphere of oxygen. P-aminobenzoic acid (PABA) formed by reduction of p-nitrobenzoic acid (PNBA) [8] was measured after incubation for 60 minutes under nitrogen. Two criteria were fulfilled when these reaction conditions and $9000 \times \mathrm{g}$ supernatant fraction from adult liver were used: (1) measurable amounts of drug metabolism occurred with minimal deviation from linearity with respect to incubation time, and (2) the concentration of the HMDM system components, rather than substrate concentration, appeared to limit the amount of hexobarbital, aminopyrine, and PNBA metabolized. The Student ' $\mathrm{t}$ ' test was used [17] to determine statistical significance; the level of significance chosen was $\mathrm{p}<0.05$. 


\section{Results}

The microsomal metabolism of hexobarbital, the formation of formaldehyde from aminopyrine, and the production of PABA from PNBA by liver from $\mathrm{MtT}$ bearing and control rats of various ages are depicted in figure 1 . The normal postnatal increase in the metabolism of these three compounds did not occur when liver from young tumor-bearing rats was used. No increase in the amount of hexobarbital metabolized or formaldehyde formed from aminopyrine was observed in liver from control rats after 73 days of age. In animals with $\mathrm{MtT}$, however, no increase in the hepatic metabolism of hexobarbital was observed in rats after 46 days of age followed for 230 days. The metabolism of this compound remained at a level normally observed in rats 17-31 days of age. When the hepatic formation of formaldehyde from aminopyrine was measured in MtT-bearing rats, no increase was found beyond levels seen in 17- to 31-day-old control rats. Similarly, the reduction of PNBA to form PABA by liver from $\mathrm{MtT}$-bearing rats did not exceed a level found in liver from control rats 31 days of age. Regardless of the drug (hexobarbital, aminopyrine or PNBA) used, the metabolism of each drug by liver from MtT-bearing rats did not increase by an amount similar to that seen in control animals 46 to 73 days of age. Thus, the normal increase in the hepatic microsomal metabolism of these three drugs was prevented in young rats with MtT.

In order to observe the effect of an 'inducing agent' on HMDM activity in young rats with $\mathrm{MtT}$, the metabolism of hexobarbital and formation of formaldehyde from aminopyrine by control and MtT-bearing 65day-old male rats were studied after phenobarbital pretreatment (table II). The metabolism of these two compounds was increased by phenobarbital administration to young rats with and without the tumor, but phenobarbital pretreatment increased metabolism of hexobarbital more in tumor-bearing rats than in control rats. When 27-day-old male control rats, which normally showed a low level of hexobarbital metabolism similar to that found in 65-day-old MtT-bearing rats (about $2 \mu$ moles metabolized/g liver) were pretreated with phenobarbital ( $75 \mathrm{mg} / \mathrm{kg} /$ day for 4 days), the amount of hexobarbital metabolized by 27 -day-old phenobarbital-treated rats was increased by an amount more than that found after phenobarbital pretreatment of adult rats. Implantation into rats of this pituitary tumor secreting corticotropin, somatotropin, and prolactin prevented the normal postnatal increase in HMDM activity, but it did not prevent the increase in this activity which followed phenobarbital pretreatment.

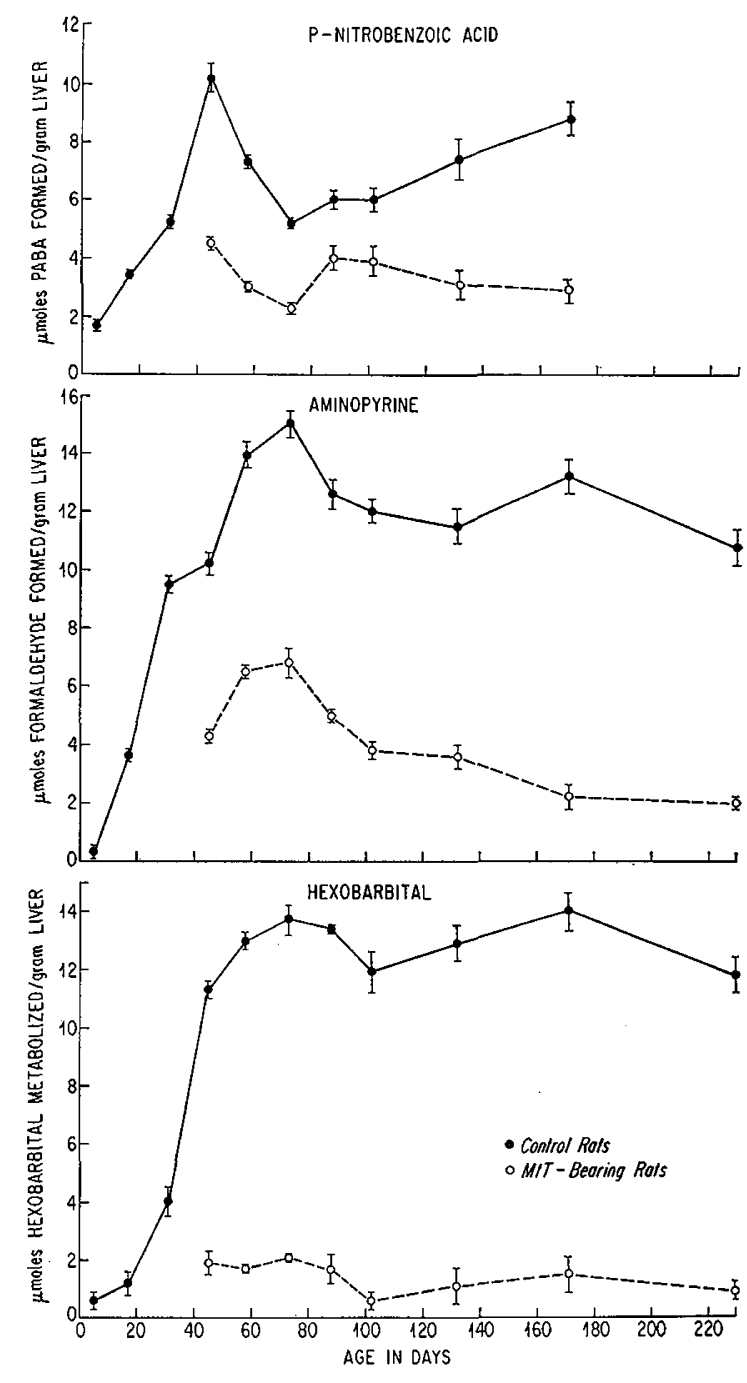

Fig. 1 . The effect of a rat pituitary tumor on the hepatic metabolism of hexobarbital, aminopyrine, and p-nitrobenzoic acid in male rats of various ages. Two milliliters of mammotropic tumor ( $\mathrm{MtT}$ ) homogenate (equivalent to $0.5 \mathrm{~g}$ of tumor) per $100 \mathrm{~g}$ body weight were injected into male rats. The age of tumor-injected rats, the period of $\mathrm{MtT}$ growth, and the number of rats per group are described in table I. The micromoles of hexobarbital metabolized, formaldehyde formed from aminopyrine, and p-aminobenzoic acid (PABA) produced from $\mathrm{p}$-nitrobenzoic acid per gram liver are given as the mean (dots) \pm standard error of the mean (brackets). The metabolism of all three compounds by liver from MtT-bearing rats was significantly ( $p<0.05$ ) decreased, when compared with metabolism in control rats of the same age. 
Table II. Phenobarbital effect on the hepatic metabolism of hexobarbital and aminopyrine in MtT-bearing young male rats ${ }^{1}$

\begin{tabular}{lccc}
\hline Treatment & $\begin{array}{c}\text { No. of } \\
\text { rats per } \\
\text { group }\end{array}$ & & \\
\hline $\begin{array}{l}\text { Control } \\
\text { Control+ }\end{array}$ & 5 & $12.8 \pm 0.40$ & $11.6 \pm 0.80$ \\
$\quad$ phenobarbital & 5 & $17.1 \pm 0.42^{3}$ & $23.2 \pm 0.64^{3}$ \\
MtT & 5 & $1.49 \pm 0.42$ & $4.27 \pm 0.18$ \\
$\begin{array}{c}\text { MtT+ } \\
\text { phenobarbital }\end{array}$ & 3 & $8.05 \pm 0.85^{3}$ & $9.14 \pm 0.92^{3}$ \\
\hline
\end{tabular}

1 Male Fischer rats were injected subcutaneously at 16 days of age with $2 \mathrm{ml} / 100 \mathrm{~g}$ body weight of $\mathrm{MtT}$ homogenate (equivalent to $0.5 \mathrm{~g}$ of tumor/2 $\mathrm{ml}$ ). Phenobarbital sodium $(75 \mathrm{mg} / \mathrm{kg}$ ) was injected intraperitonealy once a day for four days before the rats were studied. The tumor was allowed to grow for 49 days, and the animals were 65 days old when determinations were made.

${ }^{2}$ Expressed as $\mu$ moles of hexobarbital metabolized or $\mu$ moles of formaldehyde formed from aminopyrine per gram liver \pm standard error of the mean.

3 Significance $(p<0.05)$, compared with nonphenobarbital-pretreated animals.

\section{Discussion}

When $\mathrm{MtT}$ was implanted in young rats as a source of somatotropin, corticotropin, and prolactin, the normal postnatal increase to adult levels of HMDM enzyme activity against the substrates hexobarbital, aminopyrine, and PNBA did not occur. Characteristics of the decrease in the hepatic microsomal metabolism of these three drugs in mature $\mathrm{MtT}$-bearing rats have been described $[18,19,20]$. Pituitary hormones or other factors produced by $\mathrm{Mt} T$ may have acted directly on the liver, because this decrease in drug metabolism was not mediated via the adrenals or testes [20]. The effect of this tumor on the metabolism of hexobarbital and aminopyrine did not seem to be a secondary effect of liver enlargement which occurs in MtT-bearing rats [20]. Growth of a nonpituitary tumor (adenocarcinoma R3230 AC [12]) in male rats did not produce a decrease in liver drug metabolism similar to that seen with MtT-bearing rats [19]. This finding suggested that nonhormonal factors which may be common to most tumors did not mediate this change. Although other factors present in $\mathrm{MtT}$ may have been responsible for the decrease in activity of HMDM, it must be noted that BATes et al. [2] were able to simulate some of the effects of this tumor on rat organ weight by administration of somatotropin, corticotropin, and prolactin. Preliminary studies in this laboratory indicate that the hepatic metabolism of hexobarbital and the formation of formaldehyde from aminopyrine were decreased in mature male rats that received bovine somatotropin, corticotropin, and ovine prolactin as compared with animals that received bovine serum albumin.

High levels in blood of endogenous factors in the young rat may affect the liver microsomal metabolism of some drugs. Some of these factors may be anterior pituitary hormones such as somatotropin, corticotropin, and/or prolactin. In $\mathrm{MtT}$-bearing rats with high blood levels of these three pituitary hormones [1], the liver metabolism of hexobarbital, aminopyrine, and PNBA was decreased. This decrease was observed in mature male rats described in the present study and in previous reports $[19,20]$, as well as in young males less than two months old. Hexobarbital metabolism by liver from adult rats was relatively constant with respect to the age of the animal, but, in the young rat, a postnatal increase in this metabolism continued for about the first two months of life. The liver metabolism of hexobarbital was decreased in young $\mathrm{MtT}$ bearing rats compared with control rats of the same age. It is unclear whether this observation reflected a decrease in metabolism at one point in time or the prevention of the normal postnatal increase in metabolism of hexobarbital. If the latter situation prevailed, the development of HMDM which metabolized hexobarbital may have been prevented by the high levels of three pituitary hormones in MtT-bearing young rats. Endogenous factors which decreased hepatic microsomal drug-metabolizing enzyme activity in the adult rat were considered in this report to prevent the normal postnatal development of this enzyme system when young rats were studied.

If high blood levels of one or all three of the pituitary hormones secreted by $\mathrm{MtT}$ were responsible for the low level of liver drug metabolism found in young control rats, then a decrease in the level of thehepaticmetabolism of hexobarbital, aminopyrine, and PNBA would have been expected when high blood levels of these hormones were again present in adult rats. In MtTbearing adult rats, a decrease in the liver metabolism of these three drugs, compared with adult control animals, was observed.

In the human adult, a high level of somatotropin in blood (one of the hormones secreted by the MtT) which results in acromegaly may also affect liver drug metabolism, but in vitro measurements of HMDM activity with liver from acromegalic patients have not been reported. The high blood levels of somatrotropin found in human neonates [5], however, may be related to the decreased biotransformation of many drugs by newborn infants. 
This study does not prove, but rather suggests, that certain anterior pituitary hormones may affect the development of some liver microsomal drug-metabolizing enzymes in the young rat. A more complete analysis of this suggestion may be made when purified rat somatotropin, corticotropin, and prolactin become available.

\section{Summary}

The development of the hepatic microsomal enzyme system which metabolized hexobarbital, aminopyrine, and p-nitrobenzoic acid was studied in young control rats and in rats bearing a pituitary mammotropic tumor $(\mathrm{MtT})$. The normal increase with age in the liver enzyme system which biotransformed each compound did not occur in MtT-bearing rats. Growth of this tumor in the young rat, however, did not prevent an increase in the liver microsomal metabolism of hexobarbital or the formation of formaldehyde from aminopyrine which followed phenobarbital pretreatment. High levels of somatotropin, corticotropin, and prolactin in blood, or possibly some other unknown factors produced by this tumor, appeared to prevent the normal development of the liver enzyme system which metabolized hexobarbital, aminopyrine, and p-nitrobenzoic acid in the rat.

\section{References and Notes}

1. Bates, R.W.; Milkovic, S. and Garrison, M.D.: Concentration of prolactin, growth hormone and ACTH in blood and tumor of rats with transplantable mammotropic pituitary tumors. Endocrinology 71: 943-948 (1962).

2. Bates, R.W.; Milkovic, S. and Garrison, M.D.: Effects of prolactin, growth hormone and ACTH alone and in combination upon organ weights and adrenal function in normal rats. Endocrinology 74 : 714 (1964).

3. Cochin, J. and Axelrod, J.: Biochemical and pharmacological changes in the rat following chronic administration of morphine, nalorphine, and normorphine. J.Pharmacol. exp.Ther. 125: 105-110 (1959).

4. Cooper, J.R. and Brodie, B.B.: The enzymatic metabolism of hexobarbital (Evipal). J. Pharmacol. exp.Ther. 114: 409-417 (1955).

5. Gornblath, M.; Parker, M.L.; Reisner, S.H.; Forbes, A.E. and Daugraday, W.H.: Secretion and metabolism of growth hormone in premature and full-term infants. J. clin. Endocrin. 25: 209-218 (1963).

6. Fours, J.R.: Embryopathic activity of drugs (ed. Robson, J. M. and Smith, R. L.), pp.43-55 (Ghurchill, London 1965).
7. Fours, J.R. and Adamson, R.H. : Drug metabolism in the newborn rabbit. Science 129: 897-898 (1959).

8. Fouts, J. R. and Brodie, B. B.: The enzymatic reduction of chloramphenicol, p-nitrobenzoic acid and other aromatic nitro compounds in mammals. J.Pharmacol. exp.Ther. 119: 197-207 (1957).

9. Fouts, J.R. and Hart, L.G.: Hepatic drug metabolism during the perinatal period. Ann. N.Y. Acad. Sci. 123: 245-251 (1965).

10. Furth, J.; Glifton, K.H.; Gadsden, E.L. and Buffetr, R.F.: Dependent and autonomous mammotropic pituitary tumors in rats; their somatotropic features. Canad. Res. 16: 608-616 (1956).

11. Gram, T.E.; Wilson, J.T. and Fouts, J. R. : Some characteristics of hepatic microsomal systems which metabolize aminopyrine in the rat and rabbit. J. Pharmacol. exp.Ther. 159: 172-181 (1967).

12. Hrlf, R.; Michel, I.; Garlton, B.; Freman, J.J. and Borman, A.: Biochemical and Morphologic properties of a new lactating mammary tumor line in the rat. Canad. Res. 25: 286-293 (1965).

13. Jondorf, W.R.; MAichel, R. P. and Brodie, B.B. : Inability of newborn mice and guinea pigs to metabolize drugs. Biochem. Pharmacol. 6: 352-354 (1958).

14. Kato, R.; Vassanelli, P.; Frontino, G. and Chiesara, E.: Variation in the activity of liver microsomal drug-metabolizing enzymes in rats in relation to age. Biochem. Pharmacol. 13: 10371051 (1964).

15. NASH, T.: The colorimetric estimation of formaldehyde by means of the Hantzsch reaction. Biochem. J. 55: 416-421 (1953).

16. Schenkman, J.B.; Ball, J.A. and Estabrook, R.W.: On the use of nicotinamide in assays for microsomal mixed function oxidase activity. Biochem. Pharmacol. 16: 1071-1082 (1967).

17. SNedecor, G.W.: Statistical methods (Iowa State University Press, Ames, Iowa 1956).

18. Wilson, J.T.: Hepatic drug metabolism in rats bearing a mammotropic tumor. Pharmacologist 9: 202 (1967).

19. Wilson, J.T.: The effect of a pituitary mammotropic tumor on hepatic microsomal drug metabolism in the rat. Biochem. Pharmacol. 17: 14491457 (1968).

20. Wirson, J.T.: An investigation of the decrease in the metabolism of hexobarbital, aminopyrine, and p-nitrobenzoic acid by liver from rats bearing a pituitary mammotropic tumor. J. Pharmacol. exp. Ther. 160: 179-188 (1968).

21. Requests for reprints should be addressed to: JoHN T. Wilson,, M.D., San Francisco Children's Hospital, 3700 California Street, San Francisco, Cal. 94119 (USA). 